\title{
PERENCANAAN SISTEM INFORMASI PADA PERUSAHAAN PT. XYZ
}

\author{
Purnomo Sidiq ${ }^{1}$, Yopy Nugraha ${ }^{2}$, Irdham Denny ${ }^{3}$, Demmy Dharma Bhakti ${ }^{4}$ \\ ${ }^{\#}$ Sistem Informasi, Institut Pendidikan Indonesia Garut, Jl. Terusahan Pahlawan No.23 Sukagalih Tarogong Kidul Garut, \\ Jawa Barat, \\ ${ }^{1}$ purnomosidiqeinstitutpendidikan.ac.id \\ ${ }^{2}$ yopi@institutpendidikan.ac.id \\ ${ }^{3}$ jakasumpena@gmail.com \\ ${ }^{4}$ demmy@institutpendidikan.ac.id
}

\begin{abstract}
Abstrac - PT. XYZ is a company engaged in the manufacture of sweet soy sauce, with a segment of middle class consumers, focusing on the market share of the housewives, restaurants and traders of the wheel circumference. SI/TI in the PT .XYZ at this time not integrated in the utilization of information technology by better, of course, the very necessary development of information systems with the approach of the Architecture of the Enterprise (EA) with enterprise system manufacturing for business architecture, information architecture, application architecture and technology architecture, with method Architecture Enterprise Planning (EAP) approach framework Zachman.

With planning Architecture Enterprise Planning (EAP) described in the modeling business according to the organization identified 25 business function 7 business processes, schemes of information technology are connected, the architecture of the data on the candidate data entities 41 entities, the data base tersentralisasikan accessed by all organizational units in PT. XYZ, the architecture of the application identification on candidate 41 applications, technology architecture 30 network infrastructure technology supporting business, with the aim that the process of business connected overall so that stacholder easy to plan the development of a system.
\end{abstract}

Keywords - Information Systems Architecture, EAP, Information Systems, Manufacturing

Abstrak - PT. XYZ merupakan perusahaan yang bergerak dalam pembuatan kecap manis, dengan segmen konsumen menengah kebawah, berfokus pada pangsa pasar para ibu rumah tangga, rumah makan dan pedagang roda keliling. SI/TI di PT .XYZ pada saat ini belum terintergrasi pada pemanfaatan teknologi informasi dengan baik, tentunya sangat diperlukan pengembangan sistem informasi dengan pendekatan Architecture Enterprise (EA) dengan sistem enterprise manufaktur secara arsitektur bisnis, arsitektur informasi, arsitektur aplikasi dan arsitektur teknologi, dengan metode Architecture Enterprise Planning (EAP) pada pendekatan framework Zachman.

Dengan perencanaan Architecture Enterprise Planning (EAP) dijabarkan dalam suatu pemodelan bisnis yang sesuai organisasi mengidentifikasi 25 fungsi bisnis dan 7 proses bisnis, skema teknologi informasi yang terkoneksi, arsitektur data pada kandidat entitas data 41 entitas, basis data yang tersentralisasikan diakses oleh semua unit organisasi di PT. XYZ, arsitektur aplikasi melakukan identifikasi pada kandidat 41 aplikasi, arsitektur teknologi 30 infrastruktur jaringan teknologi pendukung bisnis, dengan tujuan agar proses binis terkoneksi secara keseluruhan sehingga stacholder mudah merencanakan pengembangan sebuah sistem.

Kata Kunci - Sistem Informasi Arsitektur, EAP, Sistem Informasi Manufaktur

\section{I.PENDAHULUAN}

\section{A. Latar Belakang}

Perkembangan peradaban Teknologi informasi (TI) maupun Sistem Informasi (SI) pada dewasa ini telah membawa dampak perubahan yang sangat besar didalam dunia industri khususnya manufaktur, dengan kecangihan teknologi yang berkembang saat ini dengan sangat cepat dan modern memberikan situasi persaingan antar perusahaan manufaktur baik dengan skala kecil, menengah dan besar saling bersaing menjadi nomor satu.

Dalam upaya meningkatkan persaingan antar perusahaan manufaktur sekarang ini di era generasi industri 4.0 tentunya keberadaan TI/SI memberikan dampak dalam model proses bisnis yang lebih efisiensi, cepat, canggih, sehingga produk yang dihasilkan terjaga mutunya karena telah di dukung oleh peranan TI/SI yang sangat canggih dan moderen. 
Tentunya perkembangan dan persaingan antar perusahaan manufaktur dewasa ini yang semakin pesat tergantung pada peranan pemilik/manajemen (stacholder) dalam membuat perencanaan starategis bisnis perusahaan itu sendiri yang melihat bahwa penerapan sistem informasi manufaktur sangat penting untuk di implementasikan.

PT. XYZ merupakan perusahaan manufaktur yang mengolah bahan kedelai menjadi sebuah produk kecap dan telah berkembang dengan pesat merupakan perusahaan domestik, dalam perkembangannya PT. XYZ telah memiliki dan menerapkan sebuah sistem informasi manufaktur, tetapi dalam penerapannya masih banyak kendala, diantaranya:

1. Keberadaan penerapan konsep TI/SI di perusahaan tidak berjalan dengan secara baik, antara pemilik/manajemen (stacholder) dan para karyawan/pengguna (user) kurang memahami tentang penerapan dan fungsi dari TI/SI dikarenakan keterbatasan sumber daya manusia (SDM) sangat terbatas dalam penerapan TI/SI tersebut.

2. Dengan keterbatasan pengetahuan terhadap TI/SI memberikan gap antara para pegawai (user) dengan pemilik/manajemen (stacholder), harapan manajemen semua proses bisnis yang dilakukan menggunakan sistem informasi sedangkan para pegawai merasa tidak mampu dalam penerapan sistem informasi dikarenakan banyak sistem aplikasi yang banyak inputnya, sehingga setiap laporan sering berbeda antar divisi yang membuat banyak sekali kekeliruan.

3. Proses bisnis produksi sekarang ini dilakukan secara sistem sederhana dan konvensional/manual, sehingga peranan dari stacholder sangat berpengaruh terhadap kebijakan perusahaan sehingga banyak sistem yang berjalan sering terjadi permasalahan sehingga perlu di buatkan perencanaan sistem informasi yang baik.

Dengan berkembangnya dunia manufaktur dewasa ini tentunya pemasalahan dalam penerapan suatu sistem informasi manufaktur sangat bisa diterapakan dengan cepat dan mudah sehingga dalam perencanaan penerapan sistem informasi tidak akan mengalami permasalahn antara manajemen dengan pegawai.

Agar perkembangan industri manufaktur PT. XYZ untuk berkembang lebih besar, moderen dan terintegrasi kepada bisnis prosesnya, maka PT. XYZ membutuhkan suatu sistem informasi yang sangat baik secara komprehensif secara manajerial yang akuntabel, transparan, fleksibel serta memudahkan, sehingga pihak stacholder dan user harus bisa merencanakan kebijakan strategis sistem informasi manufaktur di PT. XYZ, diharapakan dengan penerapan rencana sistem informasi manfaktur yang terintegrasi bisa menghasilkan perencanaan strategis untuk lebih baik untuk stacholder dan user dalam upaya peningkatan mutu produksi dengan melakukan penerapan sebuah model Enterprise Architecture Planning (EAP)

Arsitektur enterprise adalah kumpulan prinsip metode, dan model yang bersifat masuk akal yang digunakan untuk mendisain dan merealisasikan sebuah struktur organisasi enterprise, proses bisnis, sistem informasi dan infrastrukturnya [1].

Dalam Enterprise Architecture Planning (EAP), merupakan suatu metode yang digunakan untuk membangun sebuah arsitektur informasi. Menurut Steven H. Spewak, Enterprise Architecture Planning adalah suatu metode pendekatan perencanaan kualitas data yang berorientasi pada kebutuhan bisnis serta bagaimana cara implementasi dari arsitektur tersebut dilakukan sedemikian rupa dalam usaha untuk mendukung perputaran roda bisnis dan pencapaian isi sistem informasi dan organisasi [2].

\section{B. Identifikasi Masalah}

Agar dalam pembuatan sebuah sistem manufaktur PT. XYZ ini tetap fokus dan berjalan baik dalam implemtasi dengan menggunakan pendekatan metode Enterprise Architecture Planning (EAP), maka harus di buatkan suatu perencanaan arsitektur sistem informasi untuk mendukung proses bisnis manufaktur agar bisa terintegritas secara menyeluruh dengan baik dan moderen, identifikasi masalah dari perencanaan sistem informasi manufaktur di PT. XYZ tersebut diatas, diantaranya:

1. Membuat suatu perencanaan arsitektur sistem unformasi yang nantinya akan dijabarkan menjadi arsitektur data, arsitektur aplikasi dan arsitektur teknologi;

2. Membuat suatu rencana kegiatan implementasi/migrasi dalam untuk penerapan arsitektur-arsitektur tersebut, di dalam sistem informasi enterprise PT. XYZ.

3. Agar tidak terjadi permasalahan sistem yang konvensional, maka perlu dibuatkan sebuah penerapan perencanaan sistem manufaktur yang cocok Dengan bisnis proses di PT. XYZ.

\section{Tujuan Penelitian}

Tujuan yang akan dicapai dalam kegiatan penelitian ini, merencanakan suatu model arsitektur sistem informasi manufaktur di PT. XYZ dengan penerapkan suatu pendekatan metode perencanaan arsitektur enterprise manufaktur yang sesuai dengan kebutuhan proses bisnis yang sesuai dilakukan oleh PT. XYZ saat ini, sehingga dapat diterapkan ke sistem informasi enterprise manufaktur PT. XYZ yang hasilnya dapat mendukung maupun menunjang proses bisnis organisasi yang berjalan secara koneksi/terhubung dan memberikan keuntungan dari hasil implementasi arsitektur yang akan dibuat, terhadap proses bisnis strategis sistem informasi, sehingga memberikan nilai tambah organisasi, kemudahan, efisien dan efektif dalam menjalankan 
proses bisnis organisasi dengan meningkatkan perusahaan manufaktur kecap PT. XYZ yang berdaya saing.

\section{A. Penelitian Terdahulu}

\section{KAJIAN TEORI}

Penelitian terdahulu yang dilakukan Tities Sumunaring Tyas judul "Perancangan Enterprise Architecture Planning (EAP) pada Proses Manajemen Aset dengan Zachman Framework (Studi Kasus Divisi Manajemen Fasilitas PT. XYZ)" Hasil dari penelitian ini adalah berupa berhasil perancangan yang telah dibuat meliputi arsitektur data, arsitektur aplikasi dan arsitektur teknologi, portofolio aplikasi berupa blueprint (cetak biru) Perancangan Enterprise Architecture Planning (EAP) dari manajemen asset [3].

\section{B. Perencanaan Strategis Informasi}

Tujuan utama perencanaan strategis informasi adalah mempersiapkan rencana bagi pengelolaan analisis, perencanaan dan pengembangan sistem berbasis komputer [4].

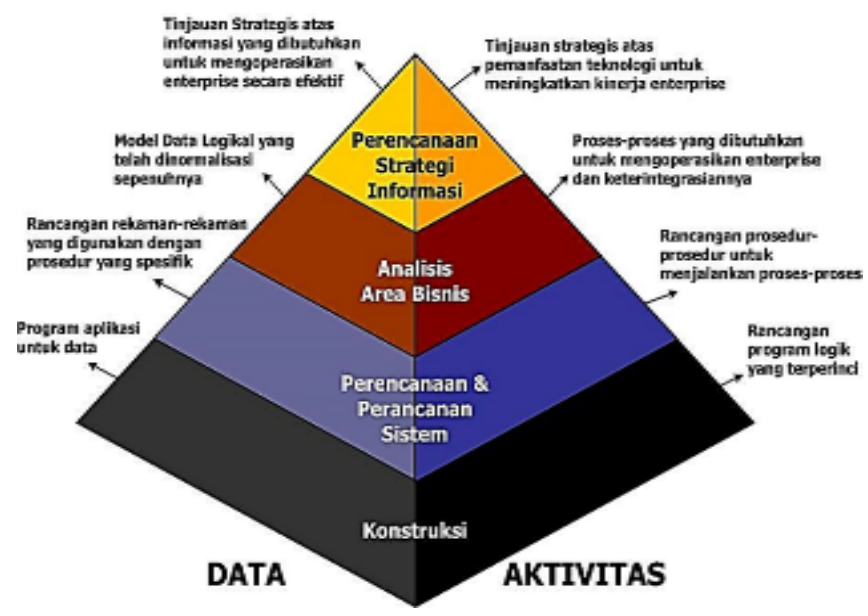

Gambar 1. Metodologi Kerekayasaan Informasi [Martin, 1990].

Dalam suatu metodologi kerekayasaan informasi, dapat dilakukan dengan melihat langkah dilihat dari dua komponen, yaitu komponen sisi data dan aktivitas. Untuk perencanaan strategi informasi di komponen sisi data, arah tinjauan strategisnya adalah terhadap kebutuhan informasi yang dibutuhkan oleh enterprise. Sedangkan di komponen sisi aktivitas, arah tinjauan strategisnya adalah dalam hal pemanfaatan teknologi untuk peningkatan kinerja enterprise.

\section{Kerangka kerja arsitektur enterprise}

Dalam perencanaan perlu dibuat suatu kerangka kerja agar semua perencanaan berjalan dengan baik, seperti yang diusulkan oleh (Ward, 2002), suatu kerangka kerja untuk mengelola perencanaan SI melalui analisis portofolio aplikasi untuk saat ini, yang diperlukan, dan untuk masa depan. Analisis portofolio aplikasi digunakan untuk merangkum titik tinjau pengembangan aplikasi bagi pemantauan implementasi arsitektur organisasi [5] .

\section{Zachman Framework}

Zachman Framework atau ZF merupakan skema atau kerangka untuk melakukan klasifikasi pengorganisasian artifak enterprise dan skema/kerangka tersebut dapat digunakan dalam enterprise architecture sebagai alat untuk membantu pemikiran/pemecahan sekaligus memahami berbagai isu dan permasalahan yang sangat komplek/ enterprise dalam mengembangkan suatu strategi agar lebih baik, efektif maupun efisien secara dinamis, model/ kerangkan yang didirancang untuk usaha mengakomodir permasalahan didalam proses bisnis yang berjalan (Zachman,1996).

Metode Zachman Framework terdiri dari 6 kolom dan 6 baris. Tiap kolom merepresentasikan fokus, abstraksi, atau topik arsitektur enterprise, yaitu: data, fungsi, jaringan, manusia, waktu, dan motivasi. Tiap baris merepresentasikan perspektif berikut:

1. Perspektif Perencana: menetapkan konteks, latar belakang, \& tujuan

2. Perspektif Pemilik: menetapkan model konseptual dari enterprise

3. Perspektif Perancang: menetapkan model sistem informasi sekaligus menjembatani hal yang diinginkan pemilik \& hal yang dapat direalisasikan secara teknis dan fisik

4. Perspektif Pembangun: menetapkan rancangan teknis \& fisik yang digunakan dalam mengawasi implementasi teknis dan fisik

5. Perspektif Subkontraktor: menetapkan peran dan rujukan bagi pihak yang bertanggung jawab untuk melakukan pembangunan sistem informasi

6. Perspektif Fungsional: merepresentasikan perspektif pengguna dan wujud nyata hasil implementasi.

\section{E. Business Process Modeling Notation (BPMN)}

BPMN adalah standar yang paling umum untuk diagram dan mendokumentasikan suatu proses bisnis. BPMN menyediakan analisis bisnis, kemampuan untuk mendefinisikan dan memahami kegiatan prosedur internal dan ekstemal bisnis melalui bentuk diagram proses bisnis, yang akan memberikan kepada organisasi kemampuan untuk mengkomunikasikan prosedur tersebut dengan cara standar.

\section{F. Four Stage Life Cycle Business System Planning} Business System Planning (BSP)

BSP merupakan suatu metode perencanaan yang dikembangkan oleh IBM sekitar pada tahun 1960. Selain mengakomodasi metodologi untuk mengidentifikasi semua kebutuhan bisnis. BSP Merupakan salah satu tool yang bisa digunakan untuk menentukan turunan dari fungsi bisnis yang terkait dengan produk/layanan yang diberikan oleh fungsi bisnis (ICH Architecture Resource Center, 2008). Ada empat siklus yang digunakan, yaitu antara lain: 
Tahap I, Requirements, planning, measurements and control

Tahap II, Acquisition

Tahap III, Stewardships

Tahap IV, Retirement

Four stage life cycle untuk menemukan turunan dari fungsi bisnis yang terkait dengan produk/layanan yang diberikan oleh fungsi bisnis tesebut. Four stage life cycle pada BSP berada pada tahap pendefinisian proses bisnis

\section{G. Enterprise Architecture Planning (EAP)}

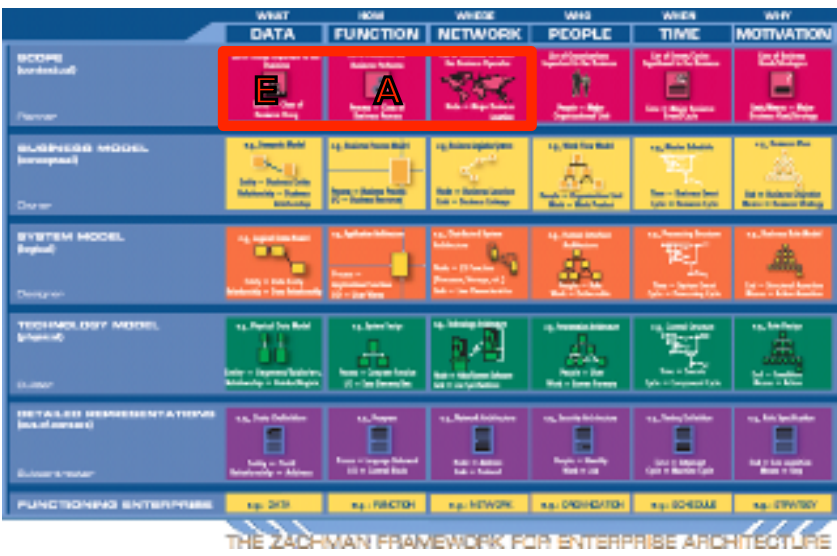

Gambar 2. Kerangka EAP dalam Zachman

Struktur perencanaan pada suatu bentuk arsitektur enterprise ditunjukkan dalam suatu gambaran komponen yang diatas dapat di jelaskan bahwa Enterprise Architecture Planning menegaskan bahwa kegiatan tersebut terdiri dari beberapa lapisan tahap diantaranya:

1. Lapisan Tahap 1 Inisiasi Perencanaan (posisi mulai kegiatan).

Dalam tahapan ini merupakan kegiatan awal dari mulainya kegiatan yang akan dilakukan. Dalam tahapan perencanaan ini dalam kegiatan difokuskan kepada ruang lingkup kegiatan/rencana kerja yang akan dibentuk, pembentukan opini ruang lingkup dan tujuan kegiatan EAP yang secara formal didefinisikan secara jelas sehingga manajemen dan stakeholder/ organisasi yang akan melakukan proses EAP akan memahami apa yang akan dicapainya nanti [6].

2. Lapisan Tahap 2 Pemodelan Proses Bisnis dan Sistem Teknologi saat ini

Dalam tahapan pemodelan proses bisnis ini merupakan identifikasi rencana proses bisnis yang akan di buat dengan mendekati pemodelan bisnis dilakukan dalam dua model, diantaranya model bisnis awal dan model bisnis lengkap, dan saling melengkapi dan di gambarkan dengan Business System Planning (BSP) dan Rantai Nilai (Value Chan).

Dalam tahapan Sistem Teknologi saat ini tahapan ini tujuan dari langkah ini adalah untuk menentukan ruang lingkup dan tujuan dari IRC dan mengembangkan rencana kerja dan jadwal untuk IRC ketika dikelola sebagai proyek terpisah dari EAP" [6].

3. Lapisan Tahap 3 Pemodelan Arsitektur Data, Arsitektur Aplikasi dan Arsitektur Teknologi

Adapun tujuan dari arsitektur data ini merupakan langkah untuk melakukan mengidentifikasi entitas potensial data yang diperlukan untuk mendukung proses bisnis. Dalam tahapan arsitektur data ini tidaklah memakan waktu yang sangat lama, biasanya hanya beberapa hari dilakukan sesuai dengan jumlah entitas yang diperlukan [6].

Tujuan arsitektur aplikasi adalah untuk mendefinisikan jenis-jenis aplikasi utama yang dibutuhkan untuk pengelolaan data dan mendukung fungsi bisnis enterprise. Aplikasi dalam enterprise arsitektur aplikasi merupakan mekanisme untuk mengelola suatu enterprise dan berhubungan dengan salah satu sel dari kerja Zachman, yaitu baris Perspektif Pemilik dan kolom Proses, tujuan dari langkah ini adalah untuk memberikan definisi-definisi yang standar untuk setiap aplikasi- aplikasi yang ada didalam arsitektur aplikasi [6].

Dalam tahapan Arsitektur Teknologi bertujuan juga untuk melakukan penentuan strategi untuk mendistribusikan aplikasi-aplikasi dan data-data, untuk menentukan platform teknologi yang akan menjadi lingkungan untuk aplikasi dan data tersebut dalam upaya untuk mendukung proses bisnis [6].

\section{H. Rencana Implementasi}

Implementasi arsitektur enterprise dilakukan untuk menghasilkan sistem informasi, pendekatan EAP menyarankan agar urutan aplikasi dilakukan dengan menggunakan matrik vs. entitas data [3].

Rencana penerapan implementasi bertujuan untuk menyusun dan menyiapkan sebuah rencana untuk melakukan pengimplementasian arsitektur, atau strategi migrasi dari posisi bisnis saat ini menuju visi posisi bisnis di masa depan yang akan datang atau disebut strategi migrasi.

\section{Portofolio Aplikasi (Portfolio Application)}

Tidak seperti pada suatu model konsep traditional portfolio yang hanya mempertemukan hubungan antara sistem aplikasi yang satu dengan yang lainnya, serta bagaimana tugas dan ruang lingkup antar sistem yang didefinisikan, bahwa pada sebuah application portfolio merupakan sebuah model perkiraan kebutuhan sistem aplikasi yang didasarkan pada kebutuhan bisnis disertai dengan definisi apa dan bagaimana sistem aplikasi tersebut memberikan suatu kontribusinya terhadap usaha pencapaian tujuan bisnis organisasi. 


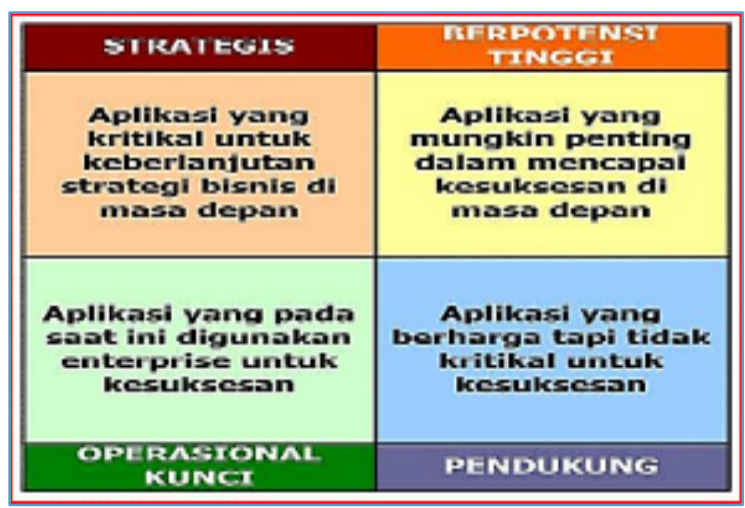

Gambar 3. Portofolio Aplikasi

Dalam pembuatan Arsitektur aplikasi berupa portofolio aplikasi yang termasuk standar dan panduan pengadaan dan pengembangan aplikasi yang diperlukan untuk mendukung fungsi dari suatu perusahaan [7].

\section{J. Sistem Manufaktur}

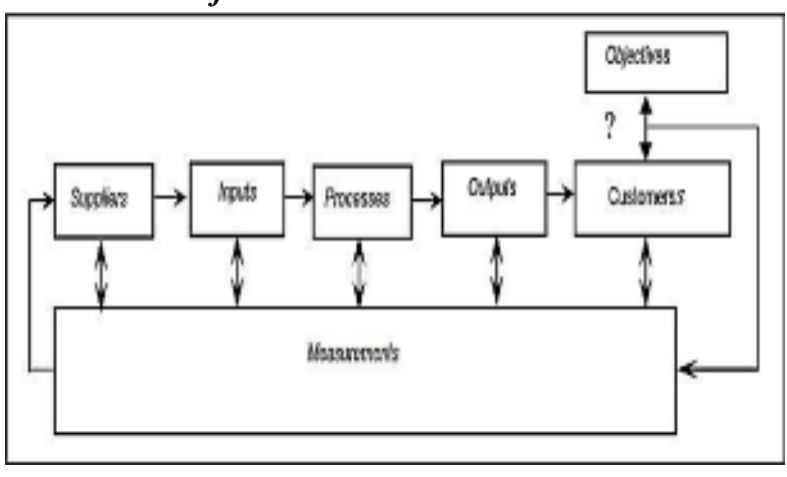

Gambar 4. SIPOCOM dalam Sistem Manufaktur

Dalam setiap sistem manufaktur harus memiliki paling sedikit tujuh elemen yang saling bekerja sama agar mencapai tujuan dari sistem itu. Untuk memudahkan mengingat ketujuh elemen dari sistem itu, maka dapat disingkat SIPOCOM (Suppliers-InputsProcesses-Outputs-Customers-Objectives-easurements) [8].

Ketujuh elemen dari sistem itu adalah:

1. Tujuan (objectives);

2. Pelanggan (customers);

3. Outputs;

4. Proses-proses (processes);

5. Inputs;

6. Pemasok (suppliers); dan

7. Pengukuran (measurements).

\section{K. Sistem Informasi}

Sistem Informasi merupakan suatu komponen yang terdiri dari serangkaian prosedur yang memproses, menganalisis, dan menyebarkan informasi untuk tujuan [9].

Sebuah sistem informasi merupakan kumpulan dari perangkat keras dan perangkat lunak komputer serta perangkat manusia yang akan mengolah data menggunakan perangkat keras dan perangkat lunak tersebut (Kristanto, 2003).

\section{Arsitektur/Architecture}

Arsitektur yang lazimnya dimengerti sebagai studi atau pekerjaan untuk merancang bangunan, sesungguhnya pengertian arsitektur tidak terbatas akan rancangan bangunan. Arsitektur adalah cara dimana sebuah sistem yang terdiri dari network, hardware dan software di strukturkan [10].

\section{III.METODE PENELITIAN}

Pada penelitian ini, langkah-langkah penelitian mengacu pada metodologi dari Enterprise Architecture Planning.

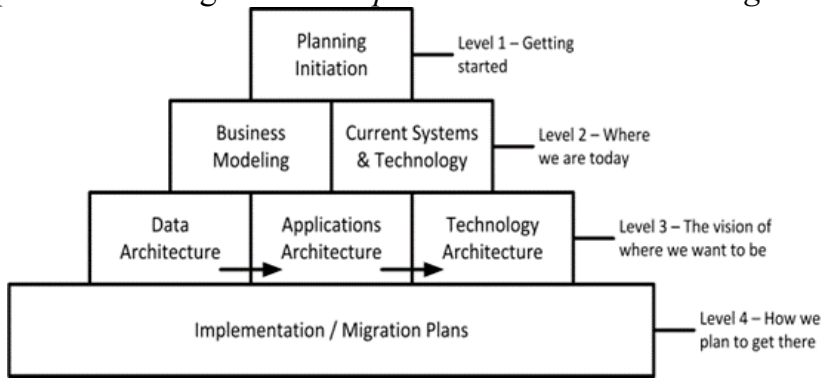

Gambar 5. Komponen Lapisan Perencanaan Arsitektur EAP

Secara studi literature tahapan ini berisi tentang uraian tentang teori temuan dan bahan penelitian yang diambil dari bahan acuan yang dijadikan penelitian, dengan melakukan identifikasi awal pada tahapan identifikasi dokumen dan observasi lapangan dan melakukan perencanaan sistem informasi arsitektur enterprise, diantaranya :

1. Planning Innitiation

a. Visi dan Misi Arsitektur Sistem Informasi

b. Ruang Lingkup dan Sasaran Pembuatan EAP

2. Bussiness Modeling

a. Dokumentasi Struktur Organisasi

b. Identifikasi Fungsi Bisnis

c. Dokumentasi Model Bisnis:

Model Rantai Nilai (Value Chain)

Business System Planning (BSP)

Four Stage Life Cycle Fungsi Bisnis Utama

d. Hubungan Fungsi Bisnis dan Organisasi

3. Sistem dan Teknologi Saat Ini

a. Katalog Penggunaan Software

b. Katalog Penggunaan Hardware

c. Katalog Jaringan saat ini

4. Temuan dan Hasil Pengamatan

5. Arsitektur Data

a. Kandidat Entitas Data

b. Identifikasi Entitas Data, Atribut Entitas, Hubungan Antar-Entitas dan Hubungan Fungsi Bisnis-Entitas Data, (1) Entitas Data, (2) Atribut Entitas Data

c. Hubungan Antar-Entitas

d. Hubungan Fungsi Bisnis dengan Entitas Data

6. Arsitektur Aplikasi 
a. Menentukan Kandidat Aplikasi

b. Identifikasi Aplikasi

c. Portofolio Kandidat Aplikasi

d. Hubungan Aplikasi dengan Fungsi Bisnis dan Organisasi

e. Analisa Dampak Terhadap Aplikasi Sekarang

7. Arsitektur Teknologi

a. Identifikasi Prinsip Teknologi dan Platform

b. Definisi Jaringan Enterprise Konseptual

c. Hubungan Platform Teknologi dengan Aplikasi dan Fungsi Bisnis

8. Rencana Implementasi

a. Urutan Pengembangan Aplikasi

b. Estimasi Usaha, Sumber Daya dan Pembuatan Jadwal Implementasi

c. Estimasi Biaya dan Keuntungan dari Rencana Implementasi

d. Menentukan Faktor Sukses dan Rekomendasi

\section{IV.HASIL DAN PEMBAHASAN}

Dalam perencanaan arsitektur system informasi ini disesuaikan kepada tahapan yang sesuai dengan kebutuhan kegiatan dalam lapisan perencanaan arsitektur tersebut.

\section{A. Inisisasi Perencanaan/Planning Innitiation}

Langkah perencanaan pada tahap inisiasi ini untuk melakukan pencetusan visi dan misi pada pada PT. XYZ, menjadikan perusahaan manufaktur yang beromset tinggi dan bermanfaat untuk masyarakat dan konsumen dengan menghasilkan jenis produk beragam berskala nasional dengan berorientasi pada kepuasan konsumen.

\section{B. Pemodelan Bisnis/Bussiness Modeling}

Langkah pemodelan bisnis untuk mengidentifikasi dari semua kandidat fungsi bisnis yang dilakukan oleh unit stackholder sehingga diperoleh pengetahuan dasar yang lengkap dan utuh, dalam fase ini dilakukan dua tahapan, yaitu tahap dokumentasi struktur organisasi, dan identifikasi fungsi bisnis dengan menggambarkan sebuah struktur organisasi yang sesuai dengan bisnis proses pada PT. XYZ.

Pada pemodelan bisnis ini pada PT, XYZ melakukan beberapa tahapan langkah yang dilakukan adalah identifikasi dan mendokumentasikan struktur organisasi, mengidentifikasi area bisnis utama dan penunjang dengan menggunakan model rantai nilai (Value Chain).

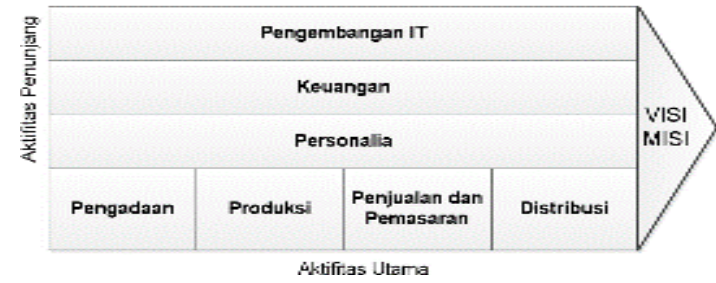

Gambar 6.Value Chain PT. XYZ
Langkah selanjutnya menentukan turunan fungsi (dekomposisi fungsi). Dekomposisi fungsi bisnis merupakan pemecahan fungsi bisnis kedalam fungsi bisnis yang lebih detail atau spesifik (sub fungsi), dengan menggunakan pedekatan metode Tool Four Stage Life Cycle dan bagan hierarki fungsi yang menghasilkan hubungan fungsi bisnis dengan organisasi PT. XYZ.

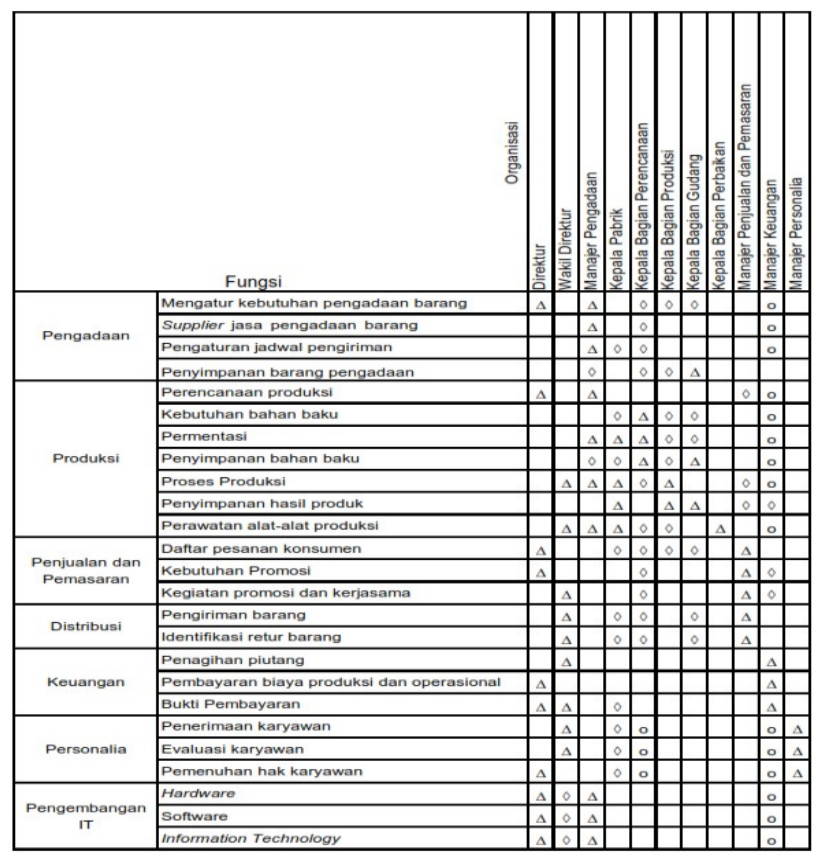

Gambar 7. Matrik Hubungan Fungsi Bisnis vs Unit Organisasi

\section{Sistem dan Teknologi Saat Ini}

Pada perencanaan tahapan ini melakukan kegiatan mendokumentasikan maupun mendefinisikan semua sistem dan platform teknologi yang akan digunakan dalam perencanaan arsitektur untuk software, hardware dan jaringan yang akan diperlukan dalam perancangan arsitektur ini. Produk utama yang akan dihasilkan dari tahap ini adalah Information Resource Catalog (IRC), IRC merupakan suatu ringkasan atau kesimpulan yang ada secara menyeluruh dengan tidak sangat mendetail maupun standar.

TABEL 1

Katalog Penggunaan Software

\begin{tabular}{|c|l|l|}
\hline No & \multicolumn{1}{|c|}{ Kategori Software } & \multicolumn{1}{|c|}{ Produk } \\
\hline 1. & Sistem Operasi & Windows 10 \\
\hline 2. & RDBMS & MySQL 5.7 \\
\hline 3. & Bahasa Pemrograman & Java \\
\hline 4. & Otomatisasi Perkantoran & $\begin{array}{l}\text { a. Ms. Office 2016 } \\
\text { b. Adobe Reader }\end{array}$ \\
\hline
\end{tabular}

TABEL 2

Katalog Penggunaan Hardware

\begin{tabular}{|c|l|l|}
\hline No & Kategori Perangkat Keras & Produk \\
\hline 1. & Perangkat computer & a. Personal \\
\hline
\end{tabular}




\begin{tabular}{|c|c|c|}
\hline & & $\begin{array}{l}\text { Computer (PC) } \\
\text { b. Notebook }\end{array}$ \\
\hline 2. & Storage & $\begin{array}{l}\text { a. Flashdisk } \\
\text { b. Harddisk } \\
\text { Internal/external } \\
\text { c. CD/DVD Room }\end{array}$ \\
\hline 3. & Input Output Device & $\begin{array}{l}\text { a. Keyboard } \\
\text { b. Scanner } \\
\text { c. Mouse } \\
\text { d. Monitor } \\
\text { e. Printer } \\
\text { f. Modem }\end{array}$ \\
\hline
\end{tabular}

TABEL 3

Katalog Jaringan saat ini

\begin{tabular}{|c|l|l|}
\hline No & \multicolumn{1}{|c|}{$\begin{array}{c}\text { Kategori Perangkat } \\
\text { Jaringan }\end{array}$} & \multicolumn{1}{c|}{ Produk } \\
\hline 1. & Networking & $\begin{array}{l}\text { a. Intranet } \\
\text { b. Internet }\end{array}$ \\
\hline 2. & Network Device & $\begin{array}{l}\text { a. Switch } \\
\text { b. RJ45 UTP } \\
\text { c. Modem }\end{array}$ \\
\hline
\end{tabular}

\section{Arsitektur Data}

Kandidat entitas yang akan diusulkan berdasarkan hasil dari semua fungsi bisnis utama yang telah diamati, tediri dari tujuh kandidat entitas yang dapat diusulkan berdasarkan fungsi bisnis, (1) Kandididat Entitas Pengadaan, (2) Kandididat Entitas Produksi, (3) Kandididat Entitas Penjualan dan Pemasaran, (4) Kandididat Entitas Distribusi, (5) Kandididat Entitas Keuangan, (6) Kandididat Entitas Personalia, (7) Kandididat Entitas Pengembangan Teknologi, entitas data berikut ini dikembangkan berdasarkan kegiatan utama dan kegiatan penunjang dalam kegiatan proses bisnis serta melihat sistem informasi yang akan digunakan di perusahaan PT. XYZ dengan melihat proses bisnis tersebut.

TABEL 4

Kandidat Entitas dan Entitas Data

\begin{tabular}{|c|c|c|}
\hline No & Kandidat Entitas & Entitas Data \\
\hline \multirow[t]{4}{*}{1} & \multirow[t]{4}{*}{ Pengadaan } & Permintaan Pembelian \\
\hline & & Supplier \\
\hline & & Pembelian \\
\hline & & Gudang \\
\hline \multirow[t]{7}{*}{2} & \multirow[t]{7}{*}{ Produksi } & Jadwal Produksi \\
\hline & & Bahan Baku \\
\hline & & Produksi \\
\hline & & Kualiti Kontrol \\
\hline & & Barang Jadi \\
\hline & & Maintenance \\
\hline & & Alat-alatProduksi \\
\hline 3 & Penjualan dan & Konsumen \\
\hline
\end{tabular}

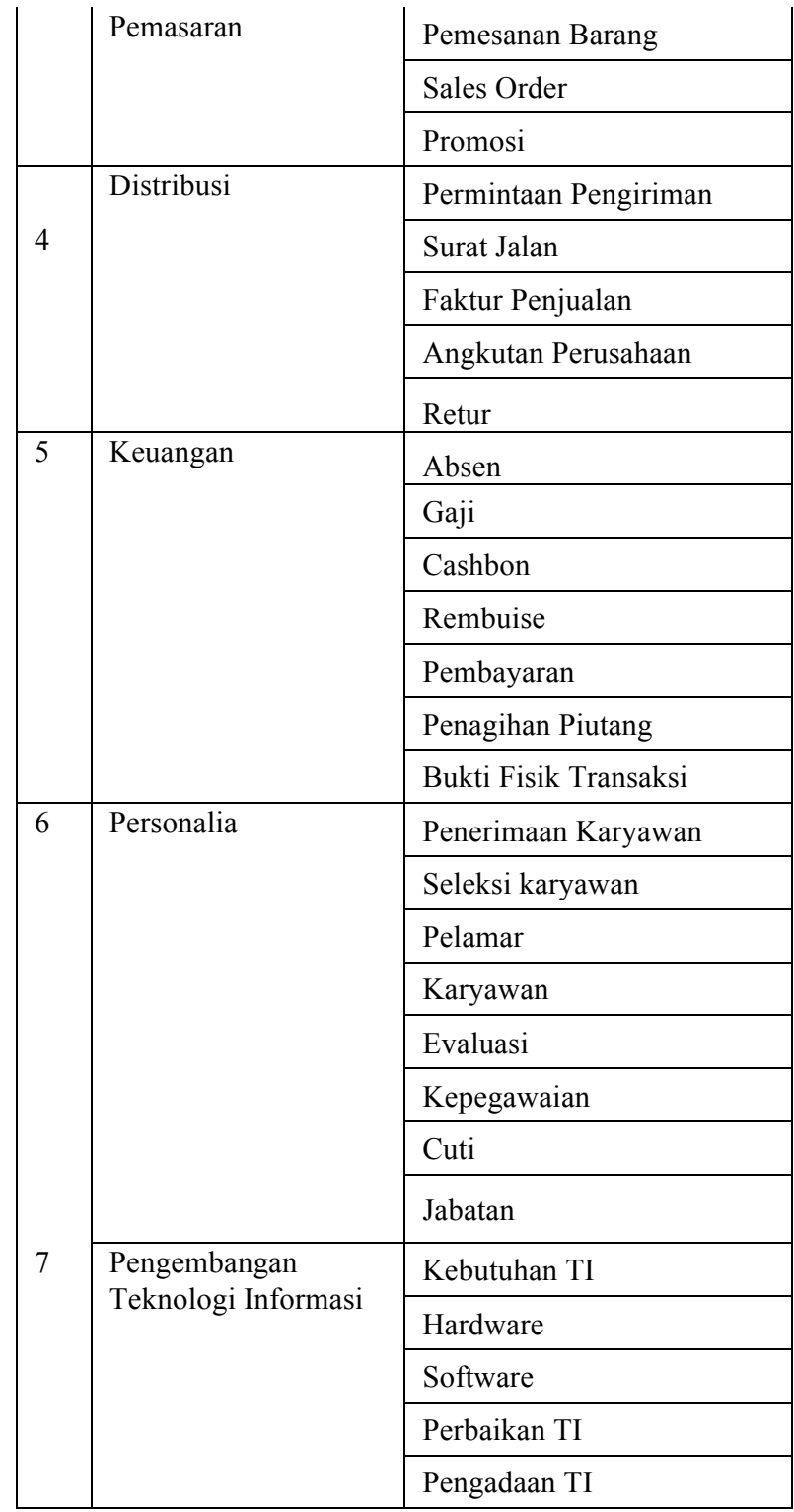

Atribut entitas data terdiri dari entitas-entitas data yang telah dikembangkan dari entitas data yang memilikin relasi antar entitas yang dapat didefinisikan sebagai orang, tempat, konsep, sesuatu atau bahkan kejadian yang memiliki arti dalam konteks bisnis. Atribut-atribut data diatas diambil dari masing-masing entitas data yang telah diperoleh serta dikelompokan dari hasil pengamatan untuk pengembangan entitas data

Setelah masing-masing dari entitas data memiliki atribut-atribut beserta kunci utama (identifier) serta hubungan dengan entitas data lainnya, hubungan dari entitas-entitas data tersebut yang digambarkan kedalam suatu gambaran diagram Entity Relationship Diagram (ERD) Conceptual Mode.

Hubungan antara era fungsi dan entitas data adalah dalam hal pembuatan, pengolahan, dan penggunaan dat untuk keperluan pemenuhan tujuan fungsi bisnis. 
Hubungan ini didefinisikan melaui matrik proses terhadap entitas data.

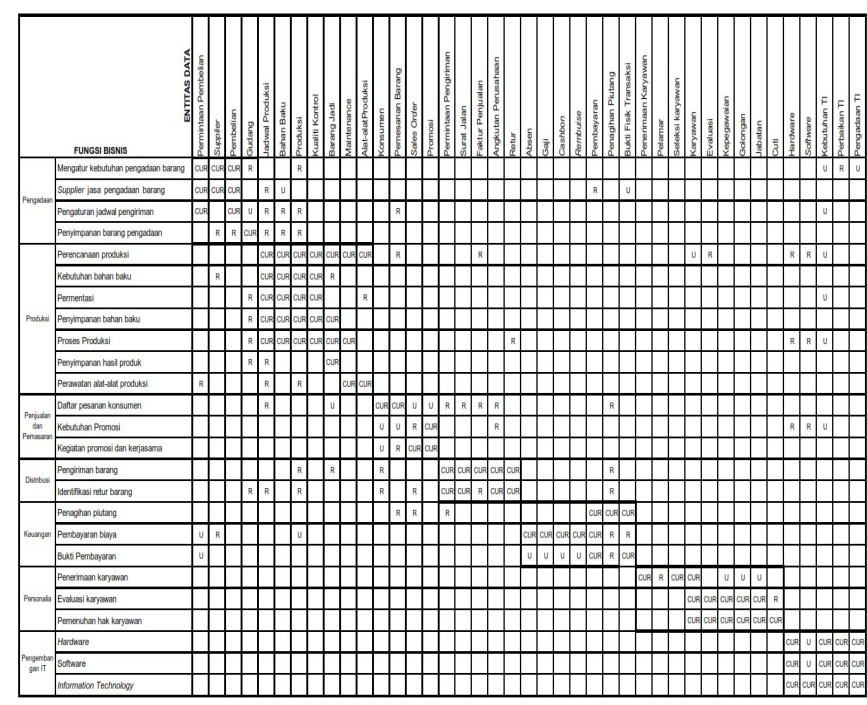

Gambar 8. Matrik Hubungan Fungsi Bisnis vs Entitas Data

\section{E. Arsitektur Aplikasi}

Dengan membuat suatu pengelompokan hasil matrik fungsi dan entitas maka akan tergambarkan kelompokkelompok (cluster) dari hasil matrik yang telah dibuat dan menentukan kelompok-kelompok aplikasi dari suatu bagian tertentu dalam matrik.

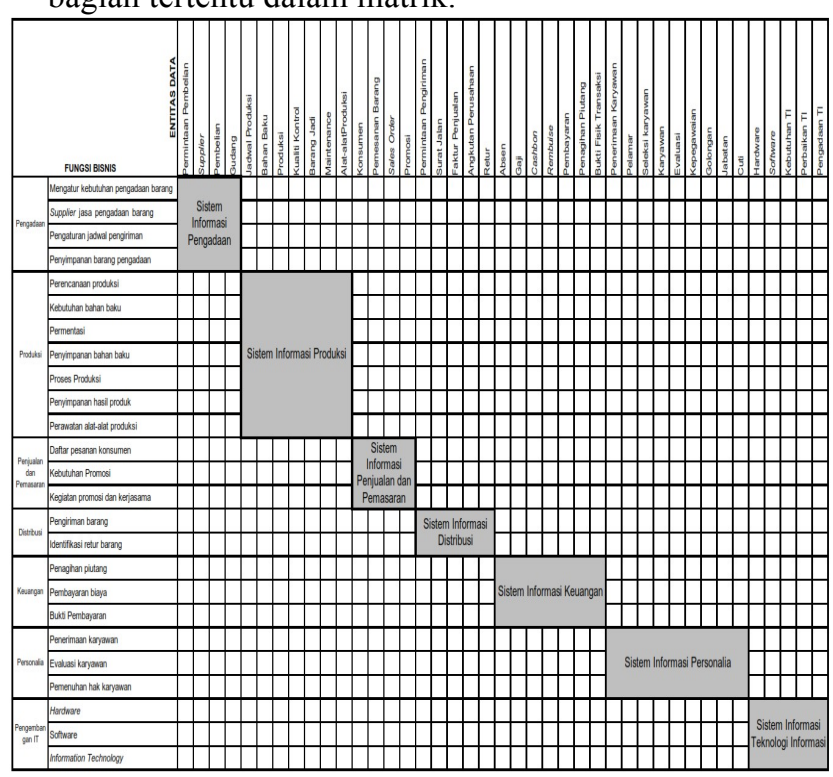

Gambar 9. Matrik Kelompok Sistem Aplikasi

Matrik yang telah dikelompokan tersebut menggambarkan suatu kelompok sistem aplikasi yang akan dibutuhkan oleh masing-masing bagian, langkah selanjutnya adalah menentukan kandidat-kandidat calon aplikasi untuk masing-msing kelompok pada sistem aplikasi yang telah dibuat.
TABEL 5

Kandidat Aplikasi

\begin{tabular}{|c|c|c|c|}
\hline \\
\hline No & $\begin{array}{c}\text { Kelompok } \\
\text { Sistem } \\
\text { Aplikasi } \\
\end{array}$ & $\begin{array}{c}\text { Nomor } \\
\text { Aplikasi }\end{array}$ & $\begin{array}{c}\text { Nama } \\
\text { Sistem Aplikasi }\end{array}$ \\
\hline \multirow{4}{*}{1} & \multirow{4}{*}{$\begin{array}{c}\text { Sistem } \\
\text { Informasi } \\
\text { Pengadaan }\end{array}$} & 1.1 & $\begin{array}{l}\text { Sistem Permintaan } \\
\text { Barang }\end{array}$ \\
\hline & & 1.2 & Sistem Supplier \\
\hline & & 1.3 & Sistem Pembelian \\
\hline & & 1.4 & Sistem Gudang \\
\hline \multirow{7}{*}{2} & \multirow{7}{*}{$\begin{array}{l}\text { Sistem } \\
\text { Informasi } \\
\text { Produksi }\end{array}$} & 2.1 & Sistem Jadwal Produksi \\
\hline & & 2.2 & Sistem Bahan Baku \\
\hline & & 2.3 & Sistem Produksi \\
\hline & & 2.4 & Sistem Kualiti Kontrol \\
\hline & & 2.5 & Sistem Produk Barang \\
\hline & & 2.6 & Sistem Maintenance \\
\hline & & 2.7 & Sistem Alat Produksi \\
\hline \multirow{4}{*}{3} & \multirow{4}{*}{$\begin{array}{l}\text { Sistem } \\
\text { Informasi } \\
\text { Penjualan } \\
\text { dan } \\
\text { Pemasaran }\end{array}$} & 3.1 & Sistem Konsumen \\
\hline & & 3.2 & Sistem Pemesanan Barang \\
\hline & & 3.3 & Sistem Sales \\
\hline & & 3.4 & Sistem Promosi \\
\hline \multirow{5}{*}{4} & \multirow{5}{*}{$\begin{array}{c}\text { Sistem } \\
\text { Informasi } \\
\text { Distribusi }\end{array}$} & 4.1 & $\begin{array}{l}\text { Sistem Permintaan } \\
\text { Pengiriman }\end{array}$ \\
\hline & & 4.2 & Sistem Surat Jalan \\
\hline & & 4.3 & Sistem Faktur Penjualan \\
\hline & & 4.4 & Sistem Kendaraan \\
\hline & & 4.5 & Sistem Retur Barang \\
\hline \multirow{7}{*}{5} & \multirow{7}{*}{$\begin{array}{c}\text { Sistem } \\
\text { Informasi } \\
\text { Keuangan }\end{array}$} & 5.1 & Sistem Absensi Karyawan \\
\hline & & 5.2 & $\begin{array}{l}\text { Sistem Penggajihan } \\
\text { Karyawan }\end{array}$ \\
\hline & & 5.3 & Sistem Cashbon \\
\hline & & 5.4 & Sistem Rembuise \\
\hline & & 5.5 & Sistem Pembayaran \\
\hline & & 5.6 & Sistem Piutang \\
\hline & & 5.7 & Sistem Bukti Pembayaran \\
\hline \multirow{8}{*}{6} & \multirow{8}{*}{$\begin{array}{c}\text { Sistem } \\
\text { Informasi } \\
\text { Personalia }\end{array}$} & 6.1 & $\begin{array}{l}\text { Sistem Penerimaan } \\
\text { Karyawan }\end{array}$ \\
\hline & & 6.2 & Sistem Pelamar \\
\hline & & 6.3 & Sistem Seleksi karyawan \\
\hline & & 6.4 & Sistem Karyawan \\
\hline & & 6.5 & $\begin{array}{l}\text { Sistem Evaluasi } \\
\text { Karyawan }\end{array}$ \\
\hline & & 6.6 & $\begin{array}{l}\text { Sistem Kepegawaian } \\
\text { Karyawan }\end{array}$ \\
\hline & & 6.7 & $\begin{array}{l}\text { Sistem Golongan } \\
\text { Karyawan }\end{array}$ \\
\hline & & 6.8 & Sistem Jabatan Karyawan \\
\hline
\end{tabular}




\begin{tabular}{|c|c|c|l|}
\hline & & 6.9 & Sistem Cuti Karyawan \\
\hline \multirow{4}{*}{7} & 7.1 & $\begin{array}{l}\text { Sistem Information } \\
\text { Technology }\end{array}$ \\
\cline { 3 - 4 } & \multirow{3}{*}{$\begin{array}{c}\text { Sistem } \\
\text { Information } \\
\text { Technology }\end{array}$} & 7.2 & Sistem Hardware \\
\cline { 3 - 4 } & & 7.3 & Sistem Software \\
\cline { 3 - 4 } & & 7.5 & $\begin{array}{l}\text { Sistem Reppair } \\
\text { Information Technology }\end{array}$ \\
\cline { 3 - 4 } & & $\begin{array}{l}\text { Sistem Update } \\
\text { Information Technology }\end{array}$ \\
\hline
\end{tabular}

Tujuan dari melakukan pendeskripsian terhadap aplikasi untuk menyediakan deskripsi singkat tentang mengenai keberadaan tentang sistem aplikasi tersebut.

TABEL 6

Deskripsi Aplikasi

\begin{tabular}{|c|c|}
\hline \multicolumn{2}{|r|}{ eski } \\
\hline $\begin{array}{l}\text { Kelompok } \\
\text { Sistem } \\
\text { Nama Sistem } \\
\text { Deskripsi }\end{array}$ & $\begin{array}{l}\text { Sistem Informasi Pengadaan } \\
: \text { SIP } \\
: \quad \text { Sistem ini bertujuan untuk : } \\
\text { 1). Pengelolaan Permintaan Barang } \\
\text { 2). Pengelolaan Supplier } \\
\text { 3). Pengelolaan Pembelian } \\
\text { 4). Pelaporan Gudang }\end{array}$ \\
\hline \multicolumn{2}{|r|}{2} \\
\hline $\begin{array}{l}\text { Kelompok } \\
\text { Sistem } \\
\text { Nama Sistem } \\
\text { Deskripsi }\end{array}$ & $\begin{array}{l}\text { Sistem Informasi Produksi } \\
\text { : } \text { SIMPRO } \\
: \quad \text { Sistem ini bertujuan untuk : } \\
\text { 1). Pengelolaan Jadwal Produksi } \\
\text { 2). Pelaporan Bahan Baku } \\
\text { 3). Pengelolaan Produksi } \\
\text { 4). Pengelolaan Kualiti Kontrol } \\
\text { 5). Pelaporan Produk Barang } \\
\text { 6). Pengelolaan Maintenance } \\
\text { 7). Pengelolaan Alat Produksi } \\
3\end{array}$ \\
\hline $\begin{array}{l}\text { Kelompok } \\
\text { Sistem } \\
\text { Nama Sistem } \\
\text { Deskripsi }\end{array}$ & $\begin{array}{l}\text { SIstem Informasi Penjualan dan } \\
\text { Pemasaran } \\
: \text { SIMPENMAS } \\
: \text { Sistem ini bertujuan untuk : } \\
\text { 1). Pengelolaan Konsumen } \\
\text { 2). Pelaporan Pemesanan Barang } \\
\text { 3). Pengelolaan Sales } \\
\text { 4). Pengelolaan Promosi }\end{array}$ \\
\hline \multicolumn{2}{|r|}{4} \\
\hline $\begin{array}{l}\text { Kelompok } \\
\text { Sistem } \\
\text { Nama Sistem } \\
\text { Deskripsi }\end{array}$ & $\begin{array}{l}\text { Sistem Informasi Distribusi } \\
: \text { SIMDIS } \\
: \text { Sistem ini bertujuan untuk : } \\
\text { 1). Pengelolaan Permintaan Pengiriman } \\
\text { 2). Pengelolaan Surat Jalan } \\
\text { 3). Pelaporan Faktur Penjualan } \\
\text { 4). Pengelolaan Kendaraan } \\
\mathbf{5}\end{array}$ \\
\hline Kelompok & : $\quad$ SIstem Informasi Keuangan \\
\hline
\end{tabular}

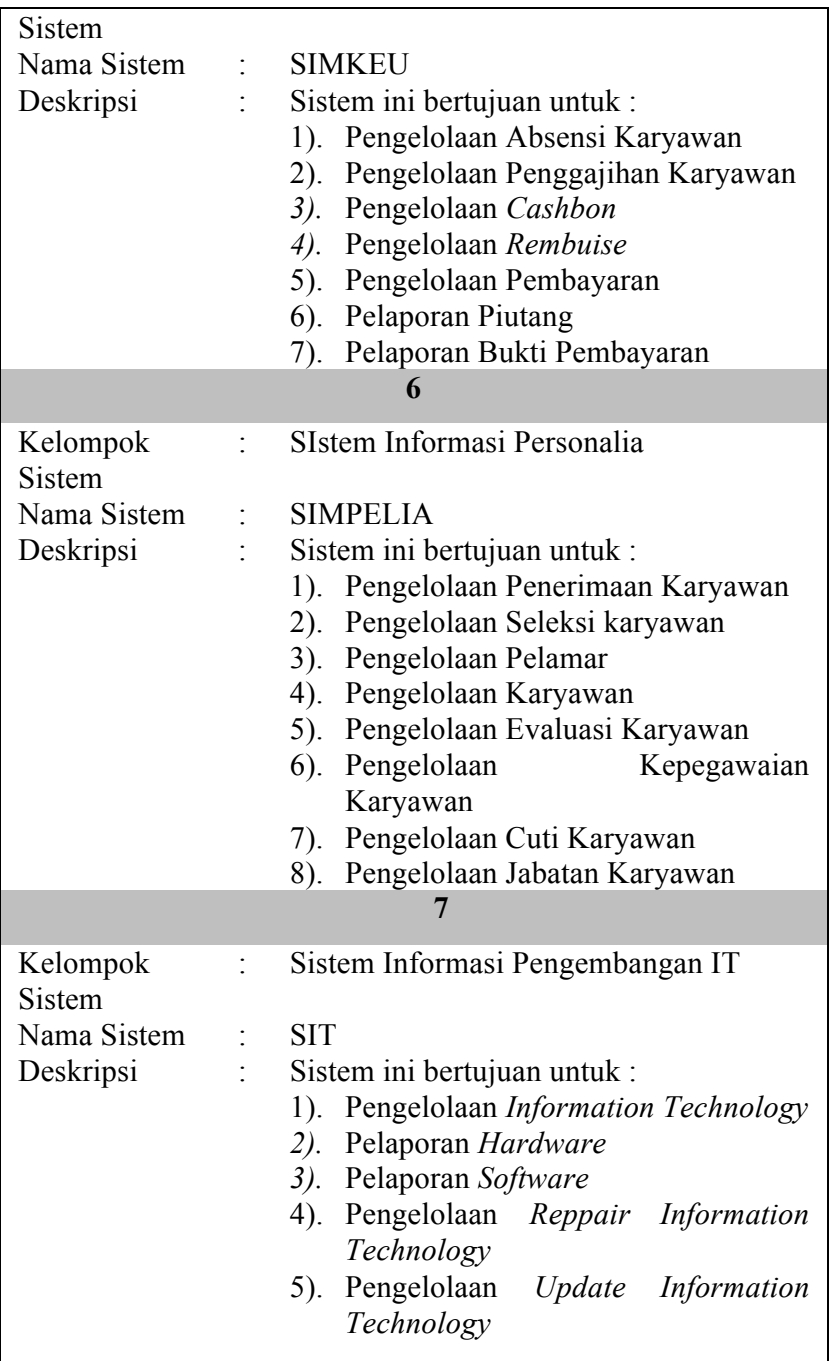

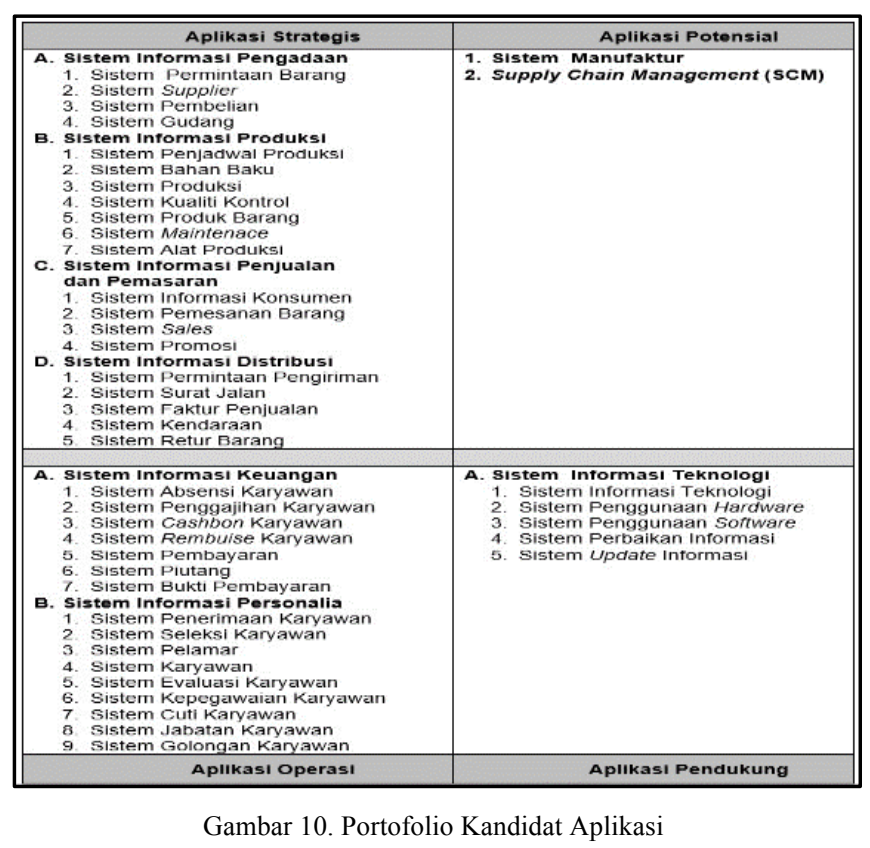


Berdasarkan daftar kandidat aplikasi portofolio kandidat aplikasi berdasarkan hasil kuadran aplikasi adalah (1) Kuadran aplikasi strategis berisi kelompok aplikasi strategis yang dibutuhkan untuk keberhasilan bisnis pada masa yang akan dating, (2) Kuadran aplikasi operasional kunci berisi tentang kelompok yang dibutuhkan untuk mendukung kegiatan operasional organisasi, (3) Kuadran aplikasi potensial berisi aplikasi yang bersifat inovatif yang mungkin dapat memperbesar peluang peningkatan kualitas dan keuntungan di masa mendatang tetapi belum dimiliki perusahaan, (4) Kuadran aplikasi pendukung berisi tentang kelompok aplikasi yang sifatnya hanya mendukung kegiatan operasional bisnis perusahaan.

Setelah dapat mendeskripikan pada setiap arsitektur aplikasi, langkah selanjutnya mengambarkan kedalam matrik, antara hubungan aplikasi dengan fungsi bisnis serta aplikasi dengan organisasi.

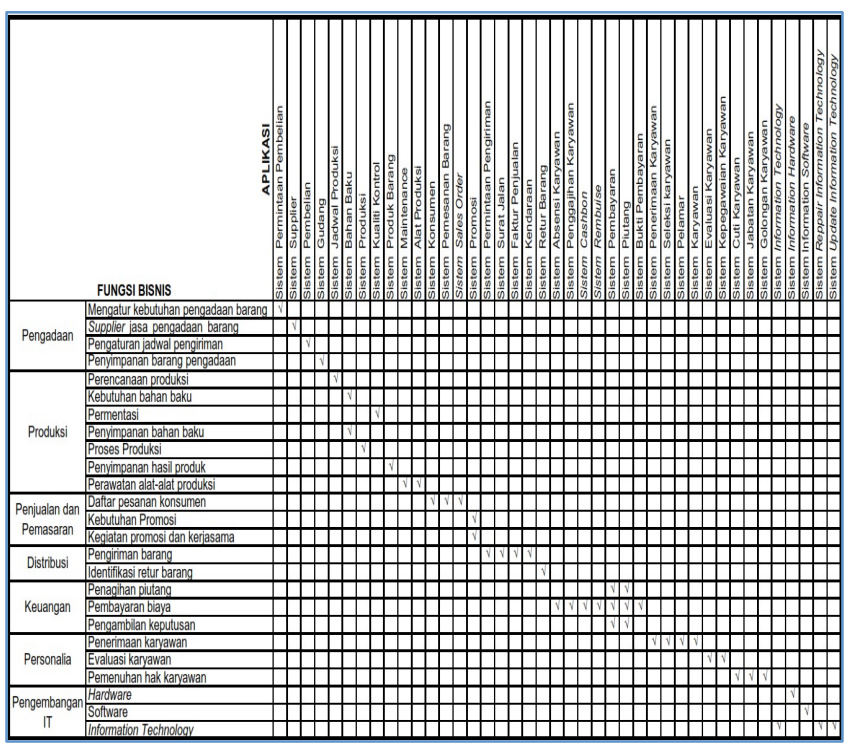

Gambar 11. Matrik Hubungan Fungsi Bisnis vs Aplikasi

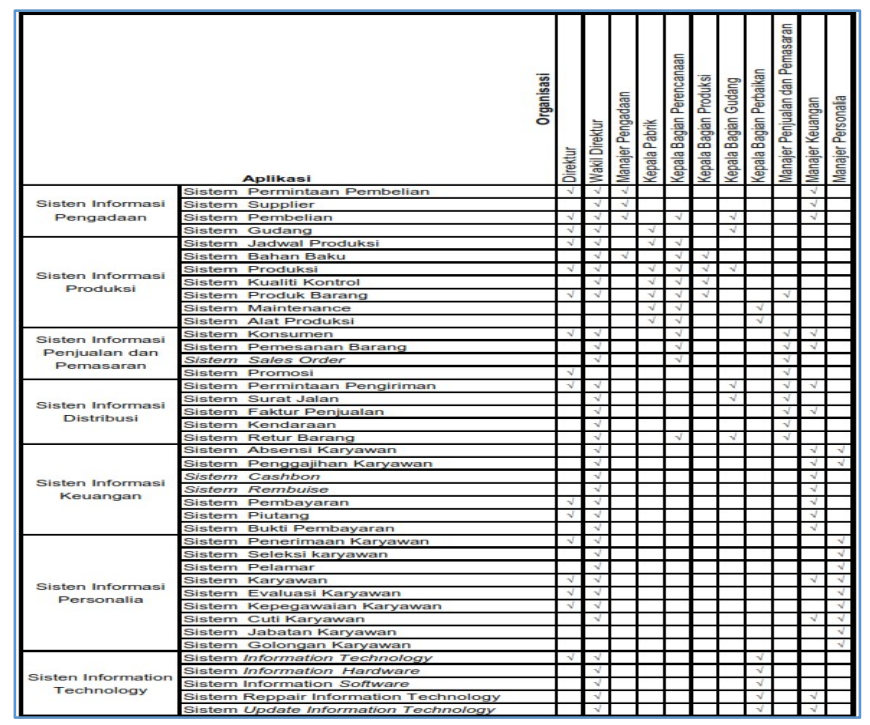

Gambar 12.Matrik Hubungan Aplikasi vs Organisasi.

\section{F. Arsitektur Teknologi}

Arsitektur teknologi merupakan definisi yang dibutuhkan untuk kegiatan dalam perencanaan, agar setiap semua kebutuhan data dan sistem informasi dapat direlisasikan sekaligus dapat dijalankan sesuai dengan perencanaan yanga telah dibuat. Tujuan dari arsitektur teknologi adalah untuk mendefinisikan bagian dari teknologi-teknologi yang diperlukan untuk menyediakan sebuah bentuk luang lingkup untuk suatu aplikasi yang fungsinya mengatur data. Inti dari perencanaan arsitektur teknologi ini adalah untuk memperoleh sebuah arsitektur konseptual dari sebuah jaringan enterprise.

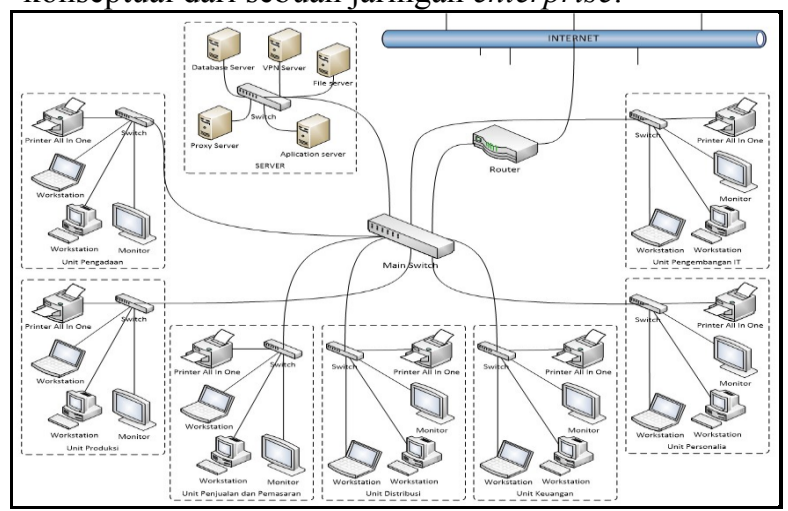

Gambar 13. Rekomendasi Jaringan konseptual Enterprise yang diusulkan

Sedangkan dilihat dari fungsi bisnis, seluruh fungsi bisnis yang ada terkait dengan semua prinsip platform teknologi yang dibuat. Dari semua fungsi bisnis yang telah diidentifikasi dalam aplikasi yang diusulkan sehingga keberadaan fungsi bisnis yang dibuat tergantung pada teknologi yang diusulkan. Dengan demikian semua teknologi yang digambarkan dalam arsitektur teknologi digunakan dengan baik secara menyeluruh dengan maksimal oleh setiap fungsi bisnis yang ada di PT. XYZ. 


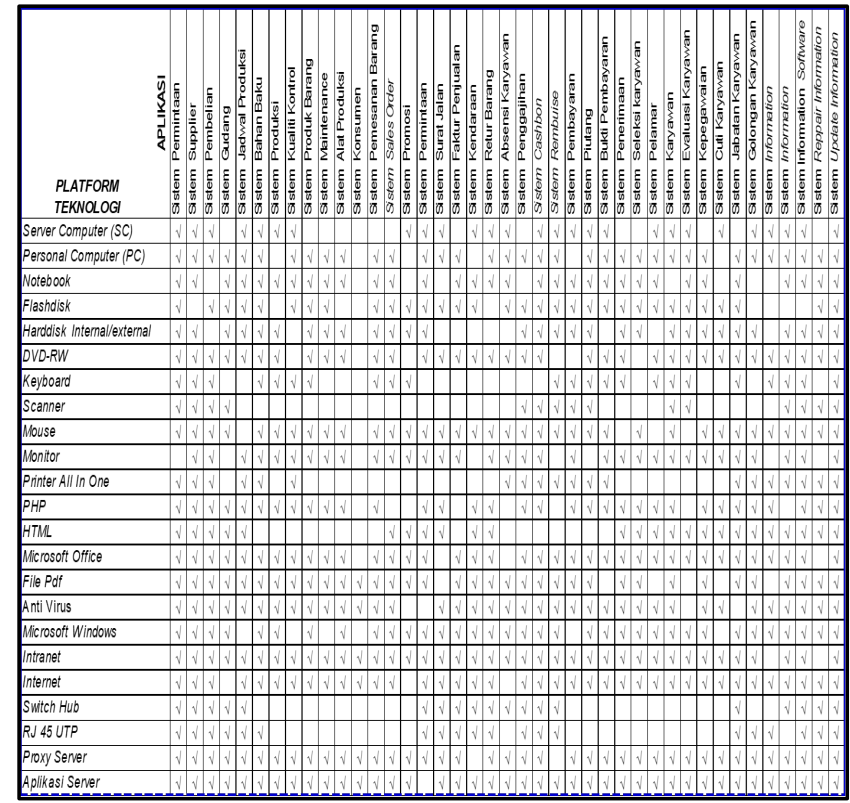

Gambar 14. Matrik Hubungan Platform Teknologi vs Fungsi Bisnis

\section{G. Rencana Implementasi}

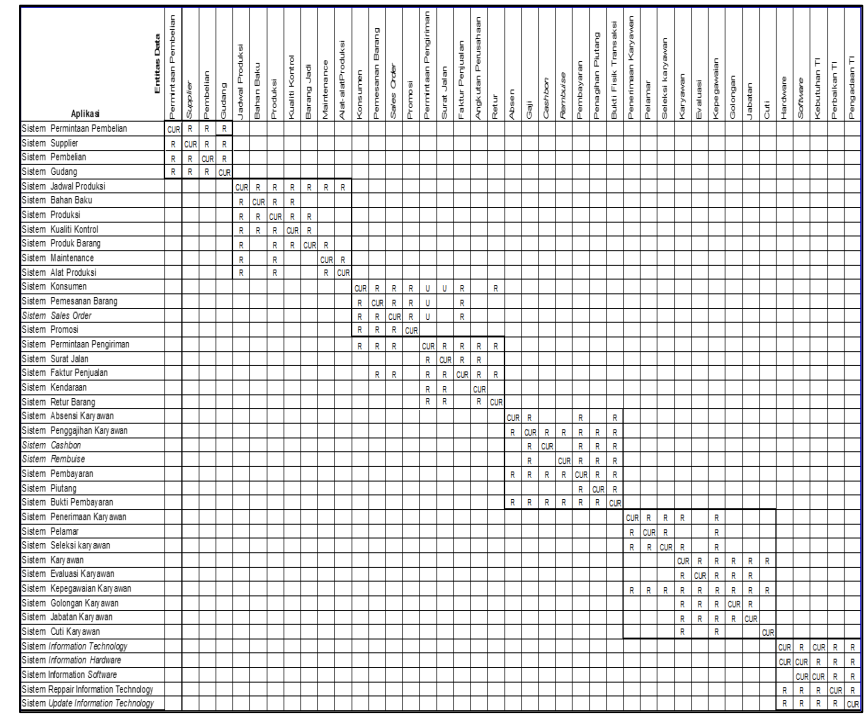

Gambar 15. Matrik Hubungan Aplikasi vs Entitas Data

Dengan telah lengkapnya semua arsitektur yang dibuat dari pembuatan arsitektur data, arsitektur aplikasi serta arsitektur teknologi, selanjutnya tinggal memformulasikan dan mempersiapkan semua arsitektur dalam tahapan rencana implementasi, tahapan implementasi merupakan tahapan terakhir yang harus dilakukan dalam perencanaan arsitektur sistem informasi enterprise pada perusahaan manufaktur di PT. XYZ, hal tersebut di buat berdasarkan pada arsitektur yang telah didefinisikan sebelumnya yaitu berdasarkan model bisnis, IRC, arsitektur data dan arsitektur aplikasi.

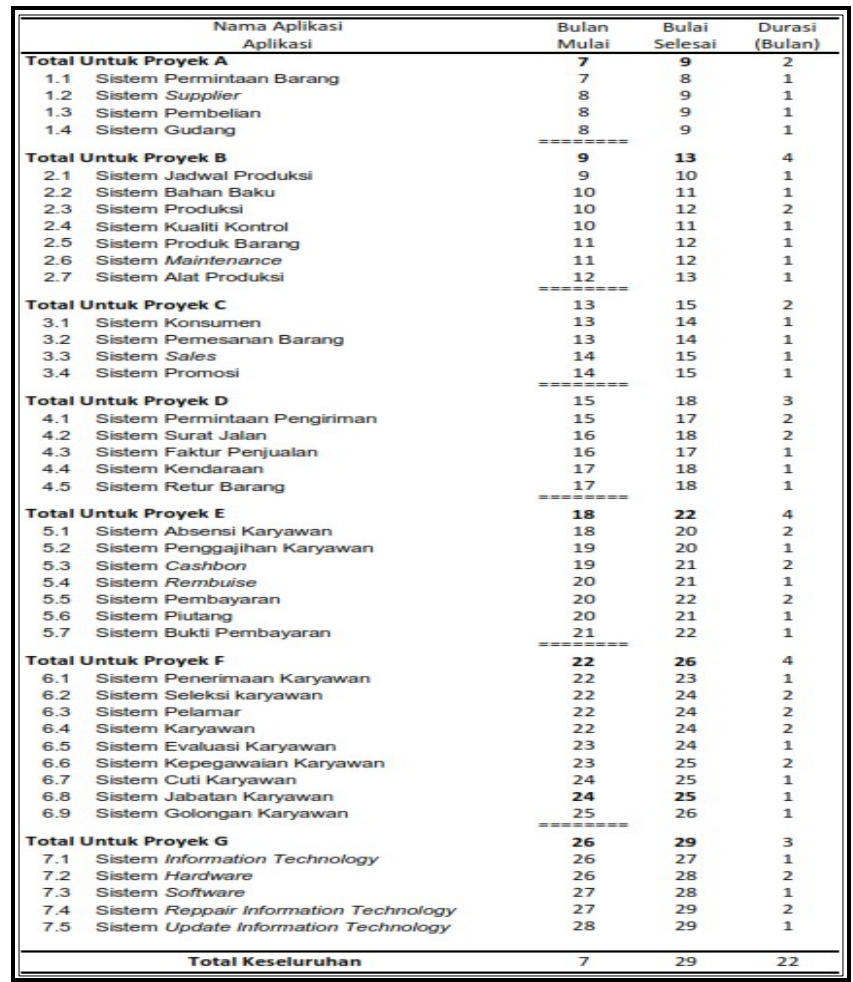

Gambar 16. Estimasi Aplikasi dan Rencana Implementasi

Dalam urutan implementasi aplikasi merupakan bagian utama yang sangat penting, dalam proses kegiatan untuk mengurutkan atau menyusun implementasi aplikasi yang akan segera dibuat dibuat, akan dibangun sebaiknya aplikasi yang bersifat yang diciptakan (create) data sebaiknya diterapkan terlebih dahulu, sebelum aplikasi yang menggunakan atau memakai (use).

Dengan pembuatan penjadwalan kegiatan implementasi, semua kegiatan yang berhubungan dengan perencanaan pembagunan sistem baru akan terkendali, penjadwalan dibuat berdasarkan kepada kebutuhan sistem yang akan dibangun serta urutan kegiatan pengimplemtasian aplikasi yang telah diusulkan, gambaran pada kegiatan penjadwalan implementasi pada pengembangan aplikasi yang dilakukan, dapat dilihat pada Estimasi Waktu Pengembangan Aplikasi, serta gambaran waktu estimasi dalam pengembangan aplikasi dapat diilustrasikan dengan gambaran sebuah roadmap rencana waktu pelaksanaan pengembangan aplikasi, roadmap. 


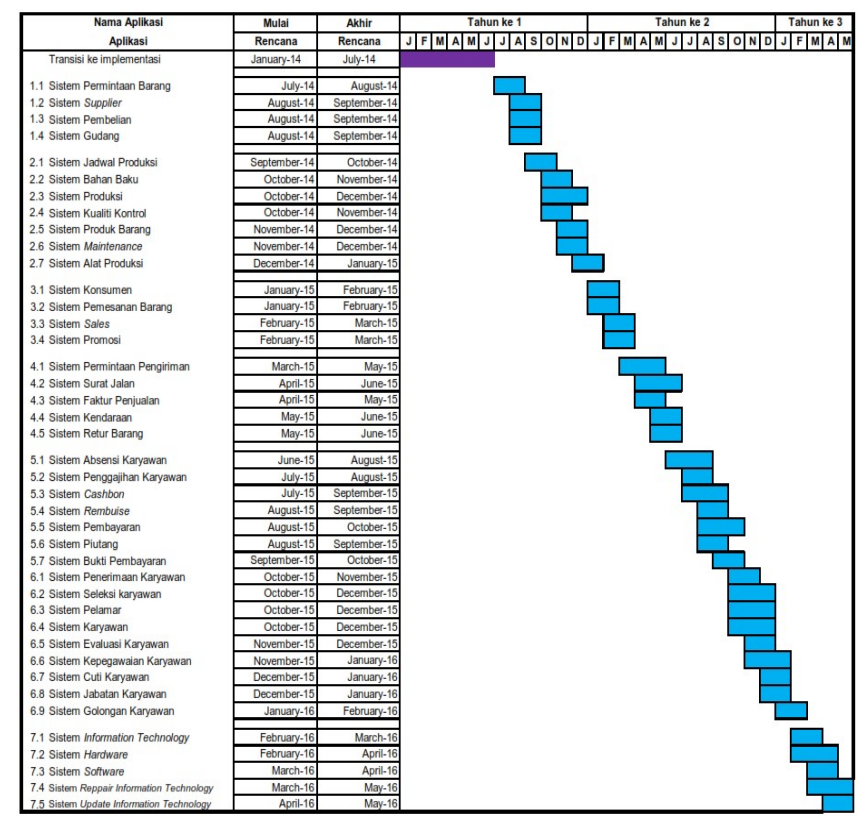

Gambar 17. Roadmap Rencana Implementasi

Biaya dan waktu merupakan faktor utama dalam pembangunan perancangan arsitektur sistem informasi. Dengan kondisi keuangan yang stabil perencanaan pengembangan aplikasi arsitektur tentunya bisa diimplementasikan, dan di tuntut semua peran dalam menjalankan agar perencanaan penerapan sistem itu bias berjalan dengan baik dan lancar, dengan waktu yang cukup lama dan jumlah biaya yang cukup besar itu merupakan komitemen bersama agar proses bisnis di PT. XYZ bisa maju.

Dalam perencanaan pembiayaan yang akan dilakukan, biaya yang dikeluarkan untuk implementasi tidak bisa diabaikan, karena faktor biaya sangat berpengaruh terhadap lancarnya kegiatan implementasi itu sendiri, tentunya komitmen pemilik/manajemen/stacholder sangat berperan dari keberlangsungnya perencanaan arsitektur sistem informasi di PT. XYZ.

\section{KESIMPULAN}

Berdasarkan hasil dari penerapan kegiatan Perencanaan Arsitektur Enterprise yang selama ini dilakukan pada PT. XYZ, bahwa dalam perancangan arsitektur enterprise bisa digunakan untuk mengembangkan sebuah penerapan pada metode Enterprise Atchitecture Planning (EAP) yaitu dengan penentuan ruang lingkup enterprise, pendekatan metodologi, Dalam kegiatan EAP berdasarkan tahapan perencanaan pembangunan arsitektur dilakukan dengan beberapa tahapan, (a) Inisiasi Perencanaan, melakukan tahapan perencanaan kegiatan pembuatan arsitektur, sehingga kegiatan tersusun sesuai tahapan metode EAP, (b) Pemodelan Bisnis, melakukan pembuatan model bisnis yang sesuai, menggambarkan suatu pengorganisasian serta mengidentifikasi 25 fungsi bisnis dan 7 proses bisnis, (c)
Sistem dan Teknologi Pada Saat Ini, melakukan dokumentasi sistem yang berjalan, sehingga tercipta skema teknologi informasi yang terkoneksi, (d) Arsitektur Data, melakukan identifikasi pada kandidat entitas data dengan sebanyak 41 entitas, dan memiliki basis data yang tersentralisasikan serta dapat diakses oleh semua unit organisasi di PT. XYZ, (e) Arsitektur Aplikasi, melakukan identifikasi pada kandidat aplikasi dengan sebanyak 41 aplikasi dan memiliki aplikasi informasi pendukung yang lebih mudah digunakan, (f) Arsitektur teknologi, melakukan identifikasi pada kandidat teknologi dengan sebanyak 30 buah dan memiliki infrastruktur jaringan teknologi pendukung bisnis yang lebih terkoneksi secara enterprise, (g) Rencana Implementasi, melakukan persiapan pengimplementasian sistem informasi dan teknologi yang baru, sehingga pembangunan proyek implementasi bisa berjalan dengan baik sesuai dengan rencana estimasi waktu serta biaya dan pembentukan tim implementasi, yang disesuaikan dengan urutan portofolio aplikasi.

Agar kegiatan proses bisnis di PT. XYZ bisa berjalan dengan baik, tentunya hal yang harus dilakukan perusahaan saat ini adalah menerapkan sistem sehingga dalam jangka waktu tertentu arsitektur enterprise yang telah direncanakan bisa diterapkan dengan sesuai dengan rencana implemtasi dan biaya yang telah disepakati agar perusahaan dapat berjalan dengan baik.

\section{DAFTAR PUSTAKA}

[1] Surendro, Kridanto, "Pemanfaatan Enterprise Architecture Planning Untuk Perencanaan Strategis Sistem Informasi," Jurnal Teknik Informatika, Institut Teknologi Bandung (ITB), 2009.

[2] Surendro, Kridanto, Pengembangan Rencana Induk Sistem Informasi. Bandung: Informatika, 2009.

[3] Tyas, Tities, S., Tarmuji, Ali, "Perancangan Enterprise Arshitecture Planning (EAP) pada Proses Manajemen Aset Dengan Menggunakan Zachman Framework (Studi Kasus Divisi Manajemen Fasilitas PT. XYZ," Jurnal Sarjana Teknik Informatika, vol. 1, no. 1, Juni 2013.

[4] Parizeau, Y, Enterprise Arshitechture for Complex Government and the Challenge of Government On-Line in Canada. Dalhousie University, 2002.

[5] Ward, Jhon and Peppard, Joe, Strategic, Planning for Information System, Jhon Wiley \& Sons, Inc., 2002.

[6] Spewak, Steven. H and Hill, Steven. C, Foreword by John A. Zachman, Enterprise Architecture Planning. Developing a Blueprint for Data, Applications and Technology. New York: A Wiley-QED Publication, 1992.

[7] Setiawati, E., Wibowo. A., Yulia, "Perancangan Sistem Informasi Enterprise Architecture di PT. ABC," Jurnal Program Studi Teknik Informatika Fakultas Teknologi Industri Universitas Kristen Petra, 2013.

[8] Gaspersz, Vincent, "Desain Sistem Manufaktur Menggunakan ERP System, "Suatu Pendekatan Praktis," Jurnal Siasat Bisnis (JSB), vol. 1, no. $6,2001$.

[9] Devi, Chenlia, "Peran Perencanaan Sistem Informasi Terhadap Kualitas Sistem," Jurnal Berkala Ilmiah Mahasiswa Akuntansi, vol. 1, no. 1, Januari 2012.

[10] Suryana, Taryana, "Perancangan Arsitektur Teknologi Informasi Dengan Pendekatan Enterprise Arshitecture Planning," Jurnal Jurusan 
p-ISSN : 2640-7363

e-ISSN : 2614-6606

Teknik Informatika Universitas Komputer Indonesia, vol. 10, no. 2, 2012. 